\title{
Cross-linking of collagen
}

\author{
Location of pyridinoline in bovine articular cartilage at two sites of the molecule
}

\author{
Simon P. ROBINS and Alexander DUNCAN \\ Rowett Research Institute, Bucksburn, Aberdeen AB2 9SB, Scotland, U.K.
}

(Received 25 April 1983/Accepted 27 June 1983)

\begin{abstract}
The location of pyridinoline in 18-month-old bovine articular cartilage was investigated by fractionation of $\mathrm{CNBr}$-derived peptides by ion-exchange chromatography and gel filtration. Two peptides, PCP1 and PCP2, were isolated and were shown to contain stoichiometric amounts of pyridinoline. From its amino acid composition and sequence studies, peptide PCP 1 was shown to comprise two $C$-terminal non-helical chains (CB14) linked through pyridinoline to the $\alpha 1$ (II)-CB12 portion of the helix. The CB14 chains appeared to be labile at their $C$-terminal ends, resulting in lower-than-expected amounts of homoserine, and only the $N$-terminal portion of the peptide was sequenced. Similar studies of peptide PCP2 showed that it contained two $N$-terminal non-helical chains (CB4) linked to the a1(II)-CB9,7 portion of the helix. The isolated peptides therefore confirmed the function of pyridinoline in stabilizing the 4D stagger of adjacent molecules. The possibility that the cross-link could act both as an intra- and an inter-microfibrillar cross-link was considered. A mechanism of formation of pyridinoline was postulated that, together with other evidence, appears to support the view that, in cartilage, pyridinoline acts primarily as an intramicrofibrillar cross-link and does not contribute to increased stability during maturation through lateral aggregation and bonding of filaments.
\end{abstract}

In the preceding paper (Robins, 1983), structural analysis of pyridinoline confirmed its existence as a 3-hydroxypyridinium compound. Evidence for the function of pyridinoline as an intermolecular crosslink was provided by analyses of Pronase (Fujimoto \& Moriguchi, 1978) or thermolysin (Fujimoto, 1980) digests of bovine tendon collagen: pyridinoline-containing peptides were isolated and, although not fully characterized, their amino acid compositions were consistent with their proposed derivation from the $C$-terminal non-helical region and a helical portion at the 'overlap' region.

The present paper describes the isolation of pyridinoline-containing peptides from $\mathrm{CNBr}$ digests of bovine articular cartilage. This form of digestion was chosen to provide larger, more easily characterized, products than those from enzymic digests. Amino acid sequence studies of the isolated peptides indicated that pyridinoline is located at two sites in the molecule, involving both the $N$ - and the $C$-terminal non-helical regions. The implications of these results on fibril organization during tissue maturation are considered.

\section{Experimental}

Materials

Phenyl isothiocyanate was purchased from Eastman-Kodak, Liverpool, U.K. Pyridine and ethyl acetate (AnalaR grade) were from $\mathrm{BDH}$ Chemicals, Poole, Dorset, U.K., and were redistilled before use. Trypsin (type III) and bacterial collagenase (type VII) were obtained from Sigma Chemical Co., Poole, Dorset, U.K. All other chemicals were of the purest grade available.

\section{Tissue preparation}

Bovine articular cartilage from femoral heads of 18-month-old animals was dissected with a scalpel, frozen in liquid $\mathrm{N}_{2}$ and powdered in a Moulinex grinder. The tissue was extracted with $4 \mathrm{M}$-guanidinium chloride at room temperature for $24 \mathrm{~h}$ to remove proteoglycans (Miller \& Lunde, 1973), washed with water and freeze-dried.

\section{Digestion with $\mathrm{CNBr}$}

The freeze-dried tissue $(2 \mathrm{~g})$ was suspended in $70 \%(\mathrm{v} / \mathrm{v})$ formic acid $(400 \mathrm{ml})$ and flushed with $\mathrm{N}_{2}$ 
for $20 \mathrm{~min}$, and solid $\mathrm{CNBr}(10 \mathrm{~g})$ was then added. Digestion was continued at $29^{\circ} \mathrm{C}$ for $5 \mathrm{~h}$, after which time the material was diluted 10 -fold with water and freeze-dried. The product was redissolved in water $(300 \mathrm{ml})$, centrifuged at $40000 \mathrm{~g}$ for $30 \mathrm{~min}$ and the supernatant solution was again freeze-dried. Analysis of acid hydrolysates of the supernatant and residue material indicated that $\mathrm{CNBr}$ digestion solubilized $97 \%$ of the hydroxyproline and $93 \%$ of the pyridinoline.

\section{Ion-exchange chromatography}

CM-cellulose chromatography was used for the initial separation of $\mathrm{CNBr}$ digests. The column $(2.6 \mathrm{~cm} \times 14 \mathrm{~cm})$ was equilibrated at $42^{\circ} \mathrm{C}$ with a sodium citrate buffer, $\mathrm{pH} 3.4$ (3.1 g of citric acid and $1.5 \mathrm{~g}$ of trisodium citrate dihydrate per litre) containing $20 \mathrm{mM}-\mathrm{NaCl}$, and peptides were eluted with a linear $\mathrm{NaCl}$ gradient formed by an Ultrograd mixer (LKB Instruments, South Croydon, Surrey, U.K.). Before chromatography, samples were dissolved in the start buffer and were dialysed at $4^{\circ} \mathrm{C}$ for $16 \mathrm{~h}$ against the same buffer: this procedure was shown to result in the loss of less than $5 \%$ of the pyridinoline fluorescence through the dialysis membrane. Re-chromatography of some peptides on CM-cellulose was performed at $42^{\circ} \mathrm{C}$ on a $1.6 \mathrm{~cm} \times$ $15 \mathrm{~cm}$ column with sodium citrate buffer, $\mathrm{pH} 3.7$ ( $2.1 \mathrm{~g}$ of citric acid and $1.5 \mathrm{~g}$ of trisodium citrate dihydrate per litre): the peptides were eluted at $60 \mathrm{ml} / \mathrm{h}$ with a linear gradient of $0-100 \mathrm{mM}-\mathrm{NaCl}$ over $960 \mathrm{ml}$. Phosphocellulose chromatography of small peptides was performed with a $1.6 \mathrm{~cm} \times 8 \mathrm{~cm}$ column at $42^{\circ} \mathrm{C}$ with $1 \mathrm{~mm}$-sodium acetate buffer, pH 3.8 (Miller, 1972).

\section{Gel filtration}

Peptide fractions from CM-cellulose chromatography were separated on a column $(2.6 \mathrm{~cm} \times 85 \mathrm{~cm})$ of Ultrogel AcA-44 run at $11 \mathrm{ml} / \mathrm{h}$ with $1 \mathrm{M}-\mathrm{CaCl}_{2} /$ $50 \mathrm{~mm}$-Tris/ $\mathrm{HCl}$ buffer, $\mathrm{pH} 7.6$, as eluent. Enzymically cleaved peptides were fractionated on a Bio-Gel P6 column $(1.6 \mathrm{~cm} \times 140 \mathrm{~cm})$ eluted at $6 \mathrm{ml} / \mathrm{h}$ with $0.1 \mathrm{M}$-acetic acid. Peptide samples from the ionexchange and Ultrogel columns were desalted on a $3.2 \mathrm{~cm} \times 50 \mathrm{~cm}$ column of Bio-Gel P2 (100-200 mesh) eluted with $0.1 \mathrm{M}$-acetic acid.

\section{Enzymic cleavage}

Peptide PCP1 $(7 \mathrm{mg})$ was dissolved in $0.1 \mathrm{M}$ Tris $/ \mathrm{HCl}$ buffer, $\mathrm{pH} 7.6(1.5 \mathrm{ml})$, containing $1 \mathrm{mM}$ $\mathrm{CaCl}_{2}$. After the addition of trypsin $(0.4 \mathrm{mg})$, digestion was continued at $37^{\circ} \mathrm{C}$ for $6 \mathrm{~h}$ or $16 \mathrm{~h}$. One drop of acetic acid was then added and the complete digest was submitted to gel filtration. Digestions with collagenase were performed under similar conditions for $8 \mathrm{~h}$.

\section{Amino acid sequence analysis}

Sequential Edman degradation of the cross-linked peptides $(250-400 \mathrm{nmol})$ was performed manually essentially by the method described by Allen (1981). The amino acid phenylthiohydantoin derivatives were identified and quantified by high-pressure liquid chromatogrpahy on a $\mu$ Bondapak $\mathrm{C}_{18}$ column (Waters Associates, Northwich, Cheshire, U.K.) with a methanol solvent system (Bhown et al., 1978). Some residues were identified by using the dansyl chloride method (Gray, 1972), and a subtractive Edman degradation procedure (Balian et al., 1971) was used for sequencing some small peptides.

\section{Amino acid analysis}

Peptides were hydrolysed in constant-boiling $\mathrm{HCl}$ in vacuo at $108^{\circ} \mathrm{C}$ for $24 \mathrm{~h}$ and were analysed on a Locarte amino acid analyser with a dual-column procedure. Pyridinoline was determined separately as described in the preceding paper (Robins, 1983).

\section{Results}

\section{Isolation of pyridinoline-containing peptides}

Initial fractionation on $\mathrm{CM}$-cellulose of $\mathrm{CNBr}$ cleavage peptides of 18 -month-old bovine articular cartilage showed that the pyridinoline fluorescence was not randomly distributed but was present in specific peptides (Fig. 1). Pooled material, designated fraction 1 and fraction 2, was re-chromatographed on Ultrogel AcA-44 (Fig. 2). Fraction 2 revealed a fluorescent peak with an apparent $M_{\mathrm{r}}$ of 9200 that appeared to comprise a single peptide (PCP1), as judged by the presence of a single band by sodium dodecyl sulphate/polyacrylamide-gel electrophoresis and a single fluorescent peak on phosphocellulose chromatography under the conditions described in the legend to Fig. 3 (results not shown). The fluorescent material in fraction 1 had an apparent $M_{\mathrm{r}}$ of 11600 , and this material was rechromatographed on CM-cellulose at $\mathrm{pH} 3.7$ to give a single major fluorescent component, designated PCP2, that was well separated from other peptides.

Amino acid compositions of the pyridinolinecontaining peptides are shown in Table 1. Peptide PCP1 corresponds closely in composition to the values for a peptide containing one $\mathrm{CB} 12$ and two CB 14 chains calculated from published data (Butler et al., 1976; Miller, 1972). Some differences in composition are, however, evident, particularly in the small amounts in peptide PCP1 of threonine, homoserine, isoleucine and tyrosine. The composition of peptide PCP2 was similar to that calculated for a peptide linking CB9,7 with two CB4 chains (Miller \& Lunde, 1973), except for slight differences in the isoleucine/leucine ratio. 


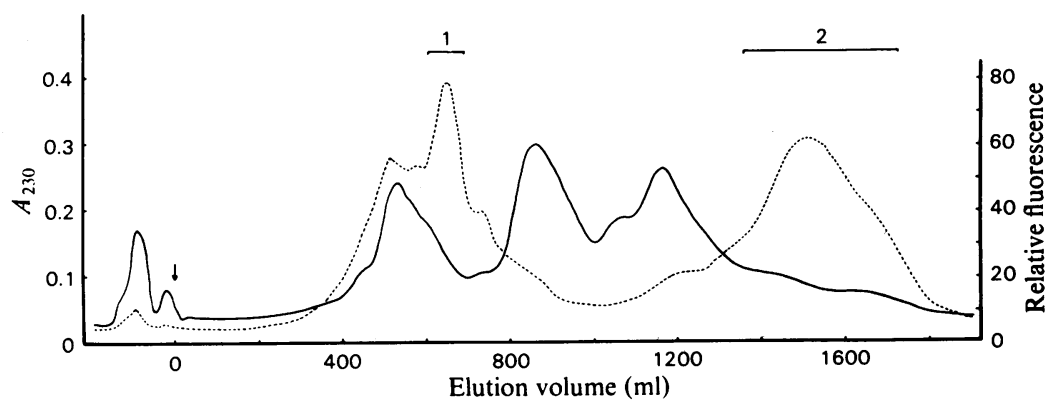

Fig. 1. CM-cellulose chromatography of cartilage collagen peptides

Approx. $250 \mathrm{mg}$ of $\mathrm{CNBr}$-cleavage peptides of bovine articular cartilage were applied to the column, previously equilibrated with sodium citrate buffer, $\mathrm{pH} 3.4$ (see the Experimental section for details). The arrow denotes the start of a linear gradient of $20-130 \mathrm{mM}-\mathrm{NaCl}$.,$- A_{230}$ of the effluent; ......, relative fluorescence emission at $400 \mathrm{~nm}$ with excitation at $295 \mathrm{~nm}$. The pooled fractions marked by the bars denoted 1 and 2 were separately desalted and rechromatographed (Fig. 2).
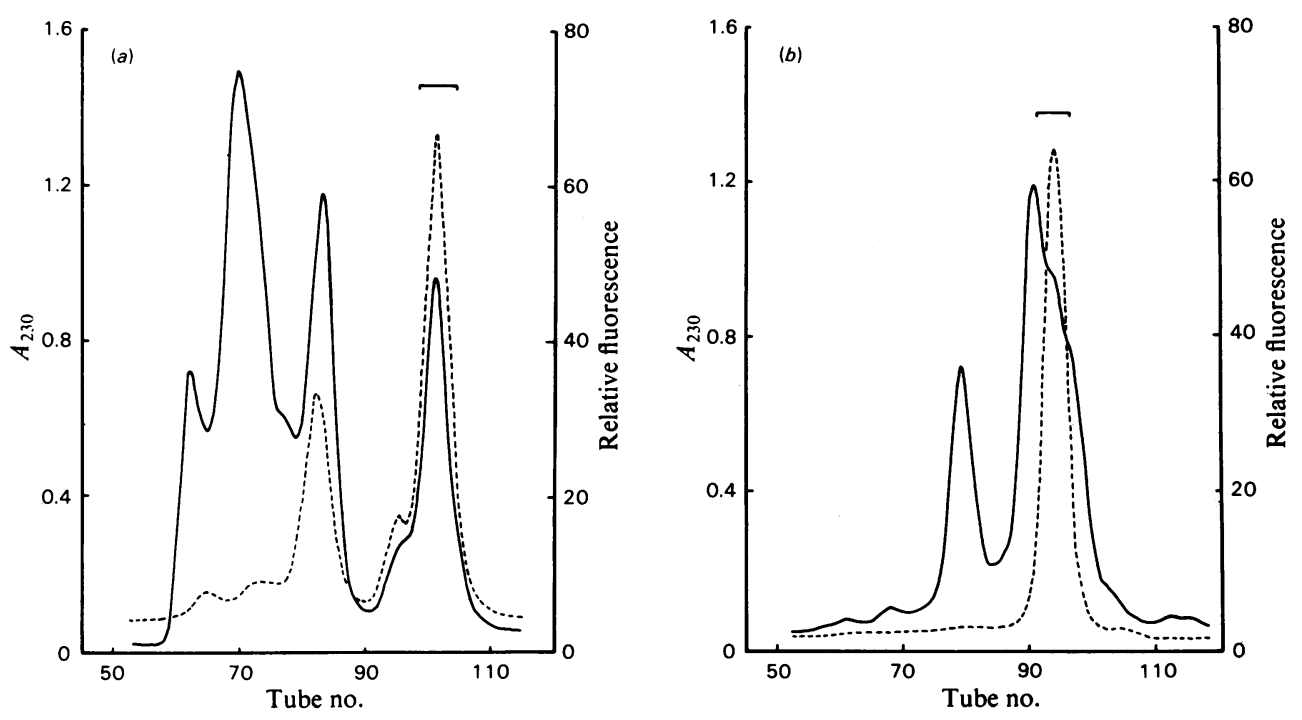

Fig. 2. Gel filtration of CM-cellulose-derived peptide fractions

Peptide fractions from CM-cellulose chromatography (Fig. 1) were chromatographed on Ultrogel AcA-44 as described in the Experimental section. - - , $A_{230}$ of the effluent; -.....-, relative fluorescence emission at $400 \mathrm{~nm}$ with excitation at $325 \mathrm{~nm}$. (a) Elution profile of fraction 2 from the CM-cellulose chromatogram: the pooled fractions marked by the bar were designated peptide PCP1. (b) Elution profile of fraction 1 from the CM-cellulose chromatogram: fractions marked by the bar were re-chromatographed on CM-cellulose.

\section{Sequence studies}

Peptides PCP1 and PCP2 were subjected to sequential Edman degradations, and the yields of amino acid phenylthiohydantoin derivatives obtained at each cycle are shown in Table 2. Generally, two major peaks were detected at each stage, although some ambiguity was introduced at cycle 7 of peptide PCP1 and cycle 2 of peptide PCP2, for which only glycine phenylthiohydantoin derivative was detected. For peptide PCP1, evidence from tryptic peptides (see below) confirmed that glycine occupied the $N$-terminal position of each chain at that stage.

After digestion of peptide PCP1 with trypsin for $6 \mathrm{~h}$, chromatography on Bio-Gel P6 separated a number of peptides, the fluorescent fractions of 
Table 1. Amino acid compositions of CNBr-cleavage peptides from bovine articular cartilage

Compositions of peptides PCP1 and PCP2 are given as mol of residues $/ \mathrm{mol}$ of peptide and are the mean values of three determinations. The compositions are compared with values for the sum of one $\mathrm{CB} 12$ and two $\mathrm{CB} 14$ chains [a1(II)-CB(12+ $14+14)$ ] calculated from the data of Butler et al. (1976) and Miller (1972) and with values for the sum of one CB9,7 chain and two CB4 chains [al(II)-CB $(9,7+4+4)]$ calculated from Miller \& Lunde (1973). Values of less than 0.2 are omitted (-)

\begin{tabular}{|c|c|c|c|c|}
\hline & \multicolumn{4}{|c|}{ Composition (mol of residue $/ \mathrm{mol}$ of peptide) } \\
\hline & PCP1 & $\begin{array}{l}\mathrm{CB}(12+ \\
14+14)\end{array}$ & PCP2 & $\begin{array}{c}\mathrm{CB}(9,7+ \\
4+4)\end{array}$ \\
\hline 3-Нyр & - & - & 1.8 & 2 \\
\hline 4-Нур & 12 & 12 & 11 & 9 \\
\hline Asp & 6.9 & 6 & 8.1 & 8 \\
\hline Thr & 1.8 & 3 & 2.9 & 3 \\
\hline Ser & 5.9 & 6 & 4.6 & 5 \\
\hline $\mathrm{Hse}^{*}$ & 1.6 & 3 & 2.6 & 3 \\
\hline Glu & 12 & 10 & 12 & 12 \\
\hline Pro & 12 & 10 & 19 & 20 \\
\hline Gly & 33 & 34 & 43 & 46 \\
\hline Ala & 8.9 & 9 & 11 & 12 \\
\hline Val & 2.3 & 2 & 1.8 & 1 \\
\hline Ile & 0.8 & 2 & 2.4 & 3 \\
\hline Leu & 4.9 & 4 & 3.9 & 3 \\
\hline Tyr & 1.7 & 3 & - & - \\
\hline Phe & 2.8 & 3 & 2.7 & 3 \\
\hline Hyl & 1.9 & $5(2) \dagger$ & 1.4 & $4(1) \dagger$ \\
\hline Lys & 2.9 & 3 & 1.9 & 1 \\
\hline His & 1.2 & 1 & 1.0 & 1 \\
\hline $\mathrm{Arg}$ & 6.5 & 6 & 7.5 & 6 \\
\hline $\begin{array}{l}\text { Pyridin- } \\
\text { oline }\end{array}$ & 0.7 & & 0.8 & \\
\hline $\begin{array}{l}\text { Total } \\
\text { residues }\end{array}$ & $\overline{120}$ & $\overline{122}$ & $\overline{140}$ & $\overline{142}$ \\
\hline
\end{tabular}

which were re-chromatographed on phosphocellulose (Fig. 3). The amino acid compositions of the isolated peptides are shown in Table 3. Although several of the peptides were impure and not fully characterized, their compositions confirmed the presence of the $\alpha 1$ (II)-CB 12 chain. Thus, according to the residue numbering system of Butler et al. (1976), peptide T2 corresponds to the $C$-terminal portion, peptide T4 comprises residues 4-23, peptide T9 comprises residues $24-27$ and peptide T3 constitutes residues $52-69$ arising from partial cleavage at hydroxylysine-69. Longer treatment with trypsin $(16 \mathrm{~h})$ resulted in increased yields of peptide T3 with a concomitant decrease in the amount of peptide T2. Peptide T7 was sequenced by sub-
Table 2. Edman degradations of peptides PCPI and PCP2

Amino acid phenylthiohydantoin derivatives from each degradation cycle were identified and quantified by high-pressure liquid chromatography (see the Experimental section). The yields (nmol) are expressed as a percentage of the starting material of peptides PCP1 $(400 \mathrm{nmol})$ and PCP2 $(250 \mathrm{nmol})$. In addition to those samples in which glycine phenylthiohydantoin derivative was a major component, small amounts of this derivative were detected at all other degradation cycles.

Amino acid phenylthiohydantoin derivative (\% yield)

\begin{tabular}{|c|c|c|}
\hline tion & PCP 1 & PCP2 \\
\hline 1 & Gly (25); $\operatorname{Ser}(8)^{*}$ & Hyp (21); Ala (32) \\
\hline 2 & Pro (28); Ala (66) & Gly (45) \\
\hline 3 & $\operatorname{Arg}(40) ;$ Phe (55) & Pro (20); Gly (33) \\
\hline 4 & Gly (28); Ala (30) & Gln/Glu (12); Phe (16) \\
\hline 5 & Pro (28); Gly (50) & Gly (16); Asn/Asp (17 \\
\hline 6 & Hyp (26); Leu (45) & Pro (10); Glu (32) \\
\hline 7 & Gly (42) & $\operatorname{Arg}(10) ;$ Glu (10) \\
\hline 8 & Pro (15); Gln/Glu (30) & Gly (16) \\
\hline 9 & Hyp (20); Arg (28) & \\
\hline 10 & Gly (20); Glu (28) & \\
\hline 11 & Lys (5); Glu (12) & \\
\hline 12 & Hyp (13); Gly (10) & \\
\hline 13 & Gly (16) & \\
\hline 14 & Asp (12) & \\
\hline
\end{tabular}

* The presence of $N$-terminal serine was confirmed by dansylation.

tractive Edman degradation and was shown to comprise mainly residues $28-36$ of the CB 12 chain. Similar analysis of peptide $\mathrm{T} 9$ indicated that the major component had the sequence Ala-Gly-LeuGly-Glx-Arg, with a minor constituent, T9a, containing in addition the $N$-terminal sequence SerAla-Phe-: again, the yield of peptide T9 was increased by longer treatment with trypsin. Peptides T5 and T6 had virtually identical amino acid compositions, despite their partial separation on phosphocellulose: slight differences in amidation may be responsible for this phenomenon. The data allow the partial sequence of peptide PCP 1 to be deduced as shown in Fig. 4. The involvement of hydroxylysine -48 of the CB 12 chain in the cross-link was indicated by the composition of the tryptic peptides, T5 and T6, which contained both histidine and threonine, amino acid residues unique to that portion of the CB12 chain (Butler et al., 1976). Collagenase digestion of these tryptic peptides followed by separation of the fluorescent components by gel filtration and phosphocellulose chromatography provided confirmatory evidence for 

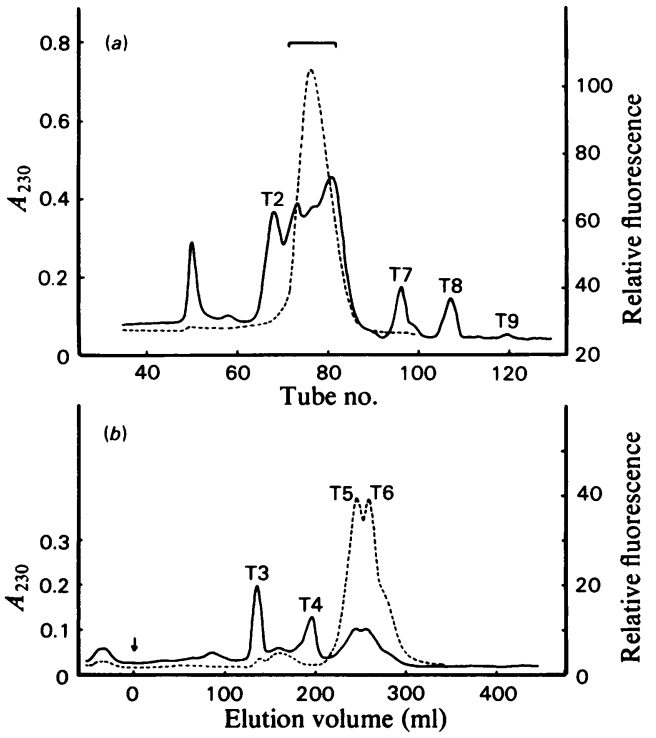

ठั

Fig. 3. Separation of peptide-PCP1-derived tryptic peptides by gel filtration and phosphocellulose chromatography

- $A_{230}$ of the effluent; --.---, relative fluorescence emission at $400 \mathrm{~nm}$ with excitation at $295 \mathrm{~nm}$. (a) After treatment of peptide PCP1 with trypsin for $6 \mathrm{~h}$, the resultant peptides were chromatographed on Bio-Gel P6 as described in the Experimental section: the peptide fractions that were freeze-dried before further analysis are indicated. The fluorescent fractions marked by the bar were submitted to ion-exchange chromatography. (b) Phosphocellulose chromatography of the fluorescent fractions from the Bio-Gel P6 column, after equilibration of the column at $42^{\circ} \mathrm{C}$ with $1 \mathrm{~mm}$-sodium acetate buffer, $\mathrm{pH} 3.8$. The peptides were eluted at $60 \mathrm{ml} / \mathrm{h}$, and the arrow indicates the start of a linear gradient of $0-0.2 \mathrm{M}-\mathrm{NaCl}$ over $480 \mathrm{ml}$. The peptide fractions designated T3-T6 were desalted for further analysis.

the amino acid composition of the $C$-terminal portion of the CB14 peptide.

\section{Discussion}

The results for peptide PCP1 show conclusively that, in cartilage collagen, pyridinoline links two $C$-terminal telopeptide chains (CB14) with the helical peptide, CB12. In addition to the presence of a stoichiometric amount of the trifunctional cross-link (Table 1), the relative yields of amino acid phenylthiohydantoin derivatives in the early cycles of the Edman degradation (Table 2) provide further evidence for the presence of three chains in the peptide. In characterizing this material, it would clearly have been preferable to effect a selective cleavage at the
Table 3. Amino acid compositions of tryptic peptides of PCP1

The compositions are given as $\mathrm{mol}$ of residue $/ \mathrm{mol}$ of peptide, and the total residues were calculated from the sum of the nearest integer values. Abbreviation: Pyd, pyridinoline.

Composition (mol of residue/mol of peptide)

$\begin{array}{lrlllllll} & \text { T2 } & \text { T3 } & \text { T4 } & \text { T5 } & \text { T6 } & \text { T7 } & \text { T8 } & \text { T9 } \\ \text { 4-Hyp } & 3.4 & 1.9 & 3.3 & 2.9 & 2.8 & 1.4 & - & - \\ \text { Asp } & 2.4 & 1.0 & 2.1 & 1.8 & 1.5 & 0.2 & - & - \\ \text { Thr } & 0.3 & - & - & 1.0 & 1.0 & - & - & - \\ \text { Ser } & 3.2 & - & - & 0.4 & 0.5 & 0.2 & 0.3 & 0.9 \\ \text { Hse* } & 0.9 & - & - & - & - & - & - & - \\ \text { Glu } & 2.9 & 1.2 & 1.3 & 3.5 & 3.6 & 1.2 & 1.1 & 1.1 \\ \text { Pro } & 1.7 & 0.2 & 2.8 & 2.8 & 2.7 & 1.9 & - & - \\ \text { Gly } & 12.3 & 6.4 & 7.2 & 7.4 & 7.3 & 3.6 & 2.4 & 1.2 \\ \text { Ala } & 3.2 & 2.8 & 1.0 & 0.3 & 0.2 & 1.2 & 1.3 & - \\ \text { Val } & 1.0 & 0.8 & - & 0.8 & 0.9 & - & - & - \\ \text { Leu } & 1.1 & 1.0 & 0.3 & 2.1 & 1.9 & - & 1.0 & - \\ \text { Tyr } & 0.9 & 0.9 & \overline{-} & 0.9 & 0.8 & - & - & - \\ \text { Phe } & 0.2 & - & 0.2 & 1.1 & 1.1 & - & 0.2 & - \\ \text { Hyl } & 1.5 & 1.8 & - & - & - & - & - & - \\ \text { Lys } & 0.4 & 0.2 & 2.8 & - & - & - & - & - \\ \text { His } & - & - & - & 0.9 & 1.0 & - & - & - \\ \text { Arg } & - & - & - & 1.0 & 0.9 & 1.0 & 1.0 & 1.0 \\ \text { Pyd } & - & - & - & 0.8 & 1.0 & - & - & - \\ \text { Total } & \overline{34} & \overline{18} & \overline{20} & \overline{28} & \mathbf{2 8} & \overline{10} & \overline{6} & \overline{4} \\ \quad \text { residues } & & & & & & & & \end{array}$

* Includes homoserine lactone.

cross-link and to identify the individual chains released. Pyridinoline is susceptible to the action of u.v. light (Robins, 1982; Sakura et al., 1982), but irradiation of peptide PCP1 was not successful in cleaving the peptide, although the pyridinoline itself was destroyed (S. P. Robins, unpublished work). The fact that the sequence of peptide $\alpha 1$ (II)-CB12 from bovine cartilage was known (Butler et al., 1976) made feasible analysis of the cross-linked peptide by direct sequencing techniques. As shown in Fig. 4, the partial sequence obtained of the $C$-terminal peptide (CB14) differed in some respects from that determined from chick complementary DNA (Miller, 1983).

The suggested sequence around the cross-link in the non-helical chains (Fig. 4) was derived mainly from the composition of the tryptic peptides T5 and T6 (Table 3) by subtracting residues $37-51$ of peptide CB12 (Butler et al., 1976), the tryptic fragment involved in cross-linking. This resulted in a composition for residues $10^{\mathrm{c}}$ to the $C$-terminus of each chain: Asp (1.0), Ser (0.2), Glu (1.8), Pro (1.0), Gly (1.2), Leu (0.5), Tyr (0.5). Similar results were obtained from the composition of a collagenasetreated tryptic peptide, except for somewhat lower values of leucine and tyrosine. The reason for 
$\mathrm{CB} 12$

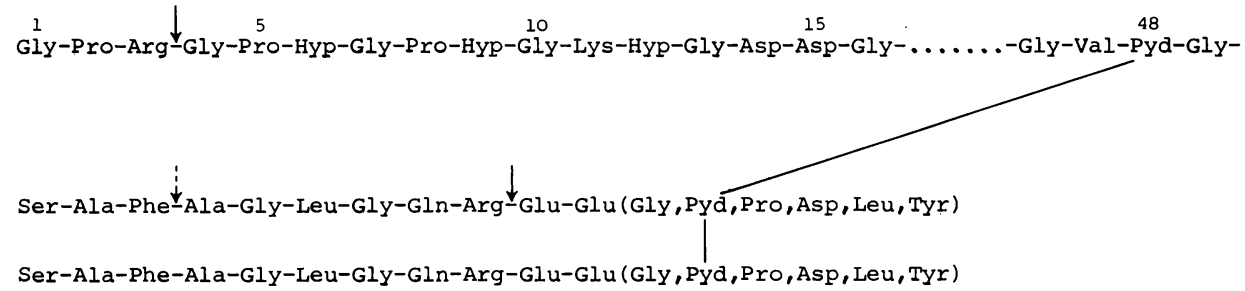

Chick $\mathrm{CB} 14$

Ser-Ala-Phe-Ala-Gly-Leu-Gly-Gln-Thr-Glu-Lys-Gly-Pro-Asp-Pro-Ile-Arg-Tyr-Met

Fig. 4. Partial amino acid sequence of peptide PCP1

The sequence was obtained by sequential Edman degradation and by analysis of tryptic peptides. The arrows indicate full cleavage sites by trypsin and the broken arrow a partial cleavage site owing to the presence of chymotryptic activity in the enzyme preparation: these gave rise to peptides T9 and T9a from the CB14 chain (see the text for details). The results of 16 cycles of the Edman degradation were consistent with the known sequence of the CB 12 chain (Butler et al., 1976), and this was used to infer the sequence of the CB14 chains. The portions of the latter in parentheses are likely sequences based on amino acid compositional data. The linkage site of pyridinoline (Pyd) is indicated. The sequence of the CB14 chain from chick cartilage is shown for comparison (Miller, 1983).

non-stoichiometric amounts of serine, leucine and tyrosine residues cannot be fully explained, but may be indicative of non-specific proteolysis of the non-helical portions of the peptide towards their $C$-terminal end. The lower than expected yield of homoserine in peptide PCP1 (Table 1) is consistent with this interpretation. This form of degradation had also been noted previously during the identification of peptide CB14 (Miller, 1972) and in attempts to isolate the bifunctional cross-linked peptide CB12 14 (E. J. Miller, personal communication). The possibility should be borne in mind that some of the observed anomalies may result from true sequence heterogeneity (Butler et al., 1977). Also, as cartilage contains a small proportion of genetically distinct collagens (Burgeson \& Hollister, 1979; Shimokomaki et al., 1980; Ayad et al., 1981), peptide heterogeneity through formation of crosslinks with these minor collagens should perhaps be considered in view of the known occurrence of covalent bonding between type I and type III collagen in human leiomyoma and calf aorta (Henkel \& Glanville, 1982).

Although peptide PCP2 has not yet been fully characterized, its amino acid composition (Table 1) suggests that it contains two $N$-terminal non-helical peptides (CB4) linked by pyridinoline to an $\alpha 1$ (II)CB9,7 chain in the helical portion of the molecule. This peptide contained only hydroxyproline and alanine as $\mathrm{N}$-terminal residues. From the direct sequence analysis (Table 2), some preliminary enzymic degradation studies (not shown) and the amino acid compositional data for the $\alpha 1$ (II)-CB4 chain given by Miller \& Lunde (1973), the probable sequence of the $N$-terminal region of the CB9,7 chain was Hyp-Gly-Pro-Gln-Gly-Pro-Arg-Gly- and that of the CB4 chain was Ala-Gly-Gly-Phe-AsnGlu(Glu,Gly,Pyd,Ala,Ala,Gly,Hse).

It can be concluded, therefore, that pyridinoline functions as a cross-link in cartilage collagen by linking both the $N$ - and the $C$-terminal ends of the molecule to points on the helix of neighbouring molecules such that the 4D stagger (Hodge \& Petruska, 1963) is stabilized (Fig. 5). In 18-monthold cartilage, the isolated peptides accounted for about $40 \%$ of the total pyridinoline fluorescence, and a number of other partially purified peptides containing pyridinoline appeared to be derived from the same location, but contained additional peptides owing to incomplete cleavage at some methionine residues.

\section{Mechanism of pyridinoline formation}

A knowledge of the mechanism of formation of pyridinoline has important implications in understanding the microfibrillar organization of collagen. From the structure of pyridinoline, it was proposed that biosynthesis of the molecule occurred through the reaction of two hydroxyallysine residues and one hydroxylysine residue (Fujimoto et al., 1978). However, Eyre (1980) suggested that interaction of two bifunctional cross-links, hydroxylysino-5-oxonorleucine, was the most likely mechanism of formation. This would necessarily involve reaction between microfilaments in register, which is accommodated by most current models of molecular pack- 
ing (Bailey et al., 1980; Piez \& Trus, 1981). An alternative mechanism summarized in Scheme 1 involves an 'aldol' condensation of hydroxyallysine with the bifunctional cross-link. This mechanism imposes less constraints on the arrangements of microfilaments, as formation of pyridinoline could also occur through an intramolecular reaction of hydroxylysino-5-oxonorleucine (Fig. 5); possible steric hindrance to the approach of two glycosylated bifunctional cross-links would also be ob- viated. Clearly, the mechanism proposed implies that pyridinoline in cartilage may act as a bifunctional cross-link rather than a trifunctional intermicrofibrillar bond. As reactive aldehyde groups may not be expected to remain available for reaction within the fibril for extended periods, it is likely that, in cartilage, further reaction of hydroxyallysine with the reducible cross-link is relatively rapid: in support of this interpretation, there is very little increase with age in the pyridinoline content of cartilage (Eyre \&

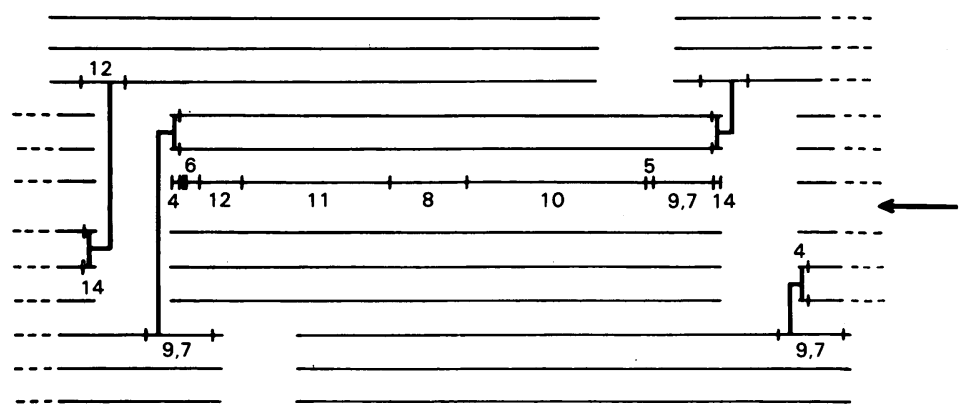

Fig. 5. Possible locations of pyridinoline cross-links in type II collagen

The diagram represents triple-chain molecules in quarter-staggered array (Hodge \& Petruska, 1963) within each microfilament. The arrow indicates the interface between two microfilaments aligned in register such that their $N$ - and $C$-terminal ends are adjacent. The order of $\mathrm{CNBr}$-cleavage peptides is shown according to the nomenclature of Miller \& Lunde (1973). The heavy lines indicate the possible locations of the cross-linked peptides isolated in the present study, those on the right of the diagram corresponding to intra-microfilament bonding and those on the left depicting inter-microfilament bonds.

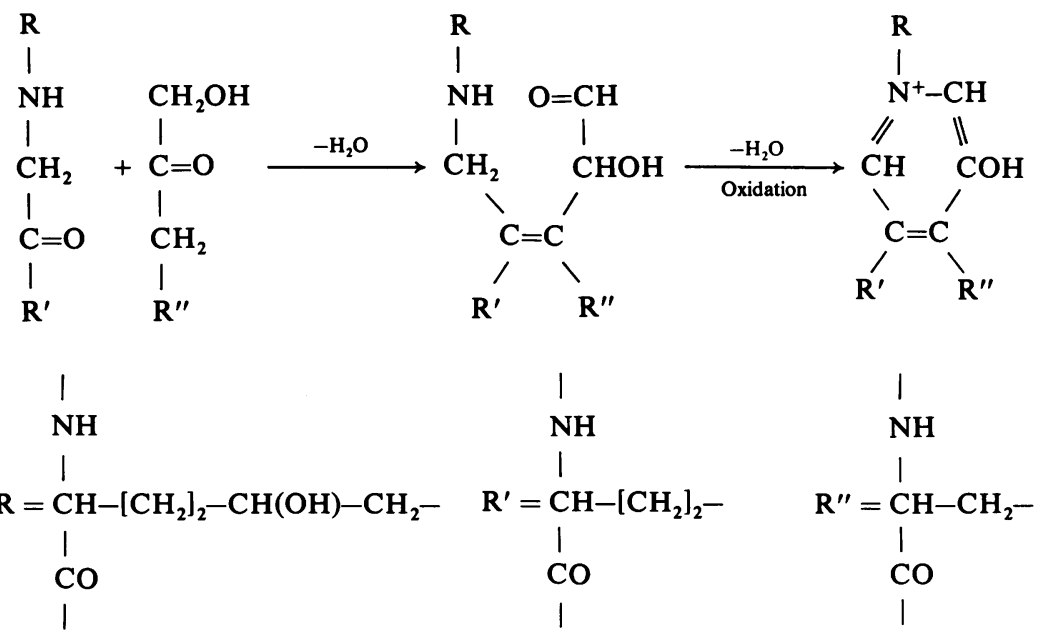

Scheme 1. Proposed mechanism of formation of pyridinoline

Reaction of hydroxylysino-5-oxonorleucine with the keto form of hydroxyallysine is proposed to occur through an 'aldol'-type condensation. This is followed by an internal condensation reaction resulting in the formation of dihydropyridinoline, which would then undergo spontaneous oxidation, analogous to the reaction proposed for the formation of desmosines (Davis \& Anwar, 1970). 
Oguchi, 1980; Robins, 1983). In other tissues, such as bone and tendon, there appears to be a gradual increase in pyridinoline content with age, and a mechanism involving intermicrofibrillar bonding may be more prevalent. However, pyridinoline is absent from 'poly- $\alpha$ ICB6', a polymer, isolated from tendon, apparently from lateral aggregation of microfibrils (Light \& Bailey, 1980a,b). By contrast, pyridinoline is present in the collagen of seacucumber tubules (Eyre \& Oguchi, 1980), a tissue in which the characteristically low tensile strength may be due to the lack of transverse bonding (Bailey et al., 1982).

It may be concluded, therefore, that, although pyridinoline constitutes a major intermolecular cross-link in several tissues and its formation probably accounts for the disappearance during maturation of the keto-amine reducible cross-links, there is as yet no evidence that pyridinoline contributes to the increased stability of mature collagens through its multifunctional cross-linking capability.

\section{References}

Allen, G. (1981) in Laboratory Techniques in Biochemistry and Molecular Biology (Work, T. S. \& Burdon, R. H., eds.), vol. 9, pp. 161-236, NorthHolland, Amsterdam

Ayad, S., Abedin, M. Z., Grundy, S. M. \& Weiss, J. B. . (1981) FE BS Lett. 123, 195-199

Bailey, A. J., Light, N. D. \& Atkins, E. D. T. (1980) Nature (London) 288, 408-410

Bailey, A. J., Gathercole, L. J., Dlugosz, J., Keller, A. \& Voyle, C. A. (1982) Int. J. Biol. Macromol. 4, 329-334

Balian, G., Click, E. M. \& Bornstein, P. (1971) Biochemistry 10, 4470-4478

Bhown, A. S., Mole, J. E., Weissinger, A. \& Bennett, J. C. (1978) J. Chromatogr. 148, 532-535
Burgeson, R. E. \& Hollister, D. W. (1979) Biochem. Biophys. Res. Commun. 87, 1124-1131

Butler, W. T., Miller, E. J. \& Finch, J. E., Jr. (1976) Biochemistry 15, 3000-3006

Butler, W. T., Finch, J. E., Jr. \& Miller, E. J. (1977) J. Biol. Chem. 252, 639-643

Davis, N. R. \& Anwar, R. A. (1970) J. Am. Chem. Soc. 92, 3778-3782

Eyre, D. R. (1980) Science 207, 1315-1322

Eyre, D. R. \& Oguchi, H. (1980) Biochem. Biophys. Res. Commun. 92, 403-410

Fujimoto, D. (1980) Biochem. Biophys. Res. Commun. 93, 948-953

Fujimoto, D. \& Moriguchi, T. (1978) J. Biochem. (Tokyo) 83, 863-867

Fujimoto, D., Moriguchi, T., Ishida, T. \& Hayashi, H. (1978) Biochem. Biophys. Res. Commun. 84, 52-57

Gray, W. R. (1972) Methods Enzymol. 25B, 333-344

Henkel, W. \& Glanville, R. W. (1982) Eur. J. Biochem. 122, 205-213

Hodge, A. J. \& Petruska, J. A. (1963) in Aspects of Protein Structure (Ramachandran, G. N., ed.), pp. 289-306, Academic Press, New York

Light, N. D. \& Bailey, A. J. (1980a) Biochem. J. 185, 373-381

Light, N. D. \& Bailey, A. J. (1980b) Biochem. J. 189, 111-124

Miller, E. J. (1972) Biochemistry 11, 4903-4909

Miller, E. J. (1983) in Connective Tissue Biochemistry (Piez, K. A., ed.), Elsevier/North-Holland, Amsterdam, in the press

Miller, E. J. \& Lunde, L. G. (1973) Biochemistry 12, 3153-3159

Piez, K. A. \& Trus, B. L. (1981) Biosci. Rep. 1, 801-810

Robins, S. P. (1982) Methods Biochem. Anal. 28, 329-379

Robins, S. P. (1983) Biochem. J. 215, 167-173

Sakura, S., Fujimoto, D., Sakamoto, K., Mizuno, A. \& Motegi, K. (1982) Can. J. Biochem. 60, 525-529

Shimokomaki, M., Duance, V. C. \& Bailey, A. J. (1980) FEBS Lett. 121, 51-54 